Supplement of Atmos. Chem. Phys., 18, 4817-4830, 2018

https://doi.org/10.5194/acp-18-4817-2018-supplement

(C) Author(s) 2018. This work is distributed under

the Creative Commons Attribution 4.0 License.

(c) (1)

Supplement of

\title{
Low-carbon energy generates public health savings in California
}

Christina B. Zapata et al.

Correspondence to: Michael J. Kleeman (mjkleeman@ucdavis.edu)

The copyright of individual parts of the supplement might differ from the CC BY 4.0 License. 


\section{Supplementary Information}

Table S1: Integrated GHG and co-benefit assessments that encompass California and examines criteria pollutant emissions, air pollution simulations, health benefits, and valued health savings for 2050 .

\begin{tabular}{|c|c|c|c|c|c|c|c|}
\hline Author & $\begin{array}{l}\text { Region, } \\
\text { resolution }\end{array}$ & $\begin{array}{l}\text { Time- } \\
\text { frame }\end{array}$ & $\begin{array}{l}\text { Energy } \\
\text { model, } \\
\text { scenario, } \\
\text { policy, } \\
\text { economics, } \\
\text { sectors }\end{array}$ & Emission Estimation & $\begin{array}{l}\text { Climate/ } \\
\text { Atmospheric } \\
\text { Model }\end{array}$ & $\begin{array}{l}\text { Short- } \\
\text { lived } \\
\text { Pollu- } \\
\text { tant(s) }\end{array}$ & $\begin{array}{l}\text { Additional } \\
\text { Impacts } \\
\text { analyzed }\end{array}$ \\
\hline This study & $\begin{array}{l}\text { California, } 4 \\
\mathrm{~km} \times 4 \mathrm{~km} \\
\left(\sim 0.05^{\circ} \mathrm{x}\right. \\
\left.0.05^{\circ}\right)\end{array}$ & 2050 & $\begin{array}{l}2 \text { scenarios } \\
\text { from CA- } \\
\text { TIMES: } \\
\text { BAU, GHG- } \\
\text { Step. } \\
\text { System-wide } \\
\text { cost } \\
\text { minimization } \\
\text { optimization. } \\
\text { (Yang, Yeh } \\
\text { et al. 2014, } \\
\text { Yang, Yeh et } \\
\text { al. 2015) }\end{array}$ & $\begin{array}{l}16 \mathrm{~km}^{2} \text { spatial } \\
\text { emissions scaling for } \\
\text { each } \\
\text { sector/mode/technol } \\
\text { ogy/fuel (fossil and } \\
\text { alterative) based on } \\
\text { literature, and } \\
\text { existing current } \\
\text { emission inventories }\end{array}$ & $\begin{array}{l}\text { UCD/CIT } \\
\text { Airshed } \\
\text { (Kleeman, } \\
\text { Cass et al. } \\
\text { 1997, } \\
\text { Kleeman and } \\
\text { Cass 2001, } \\
\text { Ying, Fraser } \\
\text { et al. 2007) }\end{array}$ & $\begin{array}{l}\mathrm{PM}_{2.5} \\
\text { (specia } \\
\text { tion } \\
\text { and } \\
\text { size re- } \\
\text { solved) } \\
\mathrm{O}_{3}\end{array}$ & $\begin{array}{l}\text { Mortality } \\
\text { (deaths, } \\
\text { death rate), } \\
\text { cost (US\$) }\end{array}$ \\
\hline $\begin{array}{l}\text { (Jacobson, } \\
\text { Delucchi et } \\
\text { al. 2014) }\end{array}$ & $\begin{array}{l}\text { California, } \\
0.6^{\circ} \times 0.5^{\circ}\end{array}$ & $\begin{array}{l}2020, \\
2030, \\
2050\end{array}$ & $\begin{array}{l}2 \text { scenarios: } \\
\text { reference, } \\
100 \% \text { Wind, } \\
\text { Water, } \\
\text { Sunlight } \\
\text { (WWS) by } \\
2050\end{array}$ & $\begin{array}{l}\text { Measured California } \\
\text { county 2010-2012 } \\
\text { PM2.5 concentration } \\
\text { and 8-hour ozone } \\
\text { level }\end{array}$ & $\begin{array}{l}\text { GATOR- } \\
\text { GCMOM, } \\
\text { Gas, Aerosol, } \\
\text { Transport, } \\
\text { Radiation, } \\
\text { General } \\
\text { Circulation, } \\
\text { Mesoscale, } \\
\text { and Ocean } \\
\text { Model } \\
\text { (Jacobson, } \\
\text { Kaufman et } \\
\text { al. 2007) }\end{array}$ & $\begin{array}{l}\mathrm{PM}_{2.5}, \\
\mathrm{O}_{3}\end{array}$ & $\begin{array}{l}\text { Mortality } \\
\text { (deaths), } \\
\text { costs (\$US), } \\
\text { job loss } \\
\text { (jobs, } \\
\text { earnings) }\end{array}$ \\
\hline $\begin{array}{l}\text { Garcia- } \\
\text { Menendez, } \\
\text { Saari et al. } \\
(2015)\end{array}$ & $\begin{array}{l}\text { US } \\
\text { contiguous, } \\
1.9^{\circ} \times 2.5^{\circ}\end{array}$ & $\begin{array}{l}2050, \\
2100\end{array}$ & $\begin{array}{l}3 \text { scenarios: } \\
\text { reference, } \\
4.5 \mathrm{~W} \mathrm{~m}^{-2} \\
\text { and } 3.7 \mathrm{~W} \\
\mathrm{~m}^{-2} \\
\text { stabilization } \\
\text { to } 2100\end{array}$ & $\begin{array}{l}\text { Emissions Prediction } \\
\text { and Policy Analysis } \\
\text { (EPPA) Model } \\
\text { (Paltsev, Reilly et al. } \\
\text { 2005) }\end{array}$ & $\begin{array}{l}\text { CAM-Chem } \\
\text { (Lamarque, } \\
\text { Emmons et } \\
\text { al. 2012) }\end{array}$ & $\begin{array}{l}\mathrm{O}_{3} \\
\mathrm{PM}_{2.5}\end{array}$ & $\begin{array}{l}\text { Years of life } \\
\text { saved, } \\
\text { Cost/Benefit } \\
\text { (\% GDP), } \\
\% \text { ton }^{-1}\end{array}$ \\
\hline
\end{tabular}


Table S2 (cont.):

\begin{tabular}{|c|c|c|c|c|c|c|c|}
\hline Author & $\begin{array}{l}\text { Region, } \\
\text { resolution }\end{array}$ & $\begin{array}{l}\text { Time- } \\
\text { frame }\end{array}$ & $\begin{array}{l}\text { Energy } \\
\text { model, } \\
\text { scenario, } \\
\text { policy, } \\
\text { economics, } \\
\text { sectors }\end{array}$ & Emission Estimation & $\begin{array}{l}\text { Climate/ } \\
\text { Atmospheric } \\
\text { Model }\end{array}$ & $\begin{array}{l}\text { Short- } \\
\text { lived } \\
\text { Pollu- } \\
\text { tant(s) }\end{array}$ & $\begin{array}{l}\text { Additional } \\
\text { Impacts } \\
\text { analyzed }\end{array}$ \\
\hline $\begin{array}{l}\text { Shindell, } \\
\text { Kuylenstierna } \\
\text { et al. (2012) }\end{array}$ & $\begin{array}{l}\text { Global, } 4^{\circ} \mathrm{x} \\
5^{\circ}\end{array}$ & 2050 & $\begin{array}{l}\text { manually } \\
\text { selected } \\
\text { policy } \\
\text { measures } \\
\text { based on } \\
\text { GAINS }\end{array}$ & $\begin{array}{l}\text { Greenhouse Gas and } \\
\text { Air Pollution } \\
\text { Interactions and } \\
\text { Synergies (GAINS) } \\
\text { model used for } \\
\text { reductions (GAINS } \\
\text { Development Team. } \\
\text { International } \\
\text { Institute for Applied } \\
\text { Systems Analysis } \\
\text { (IIASA) 2009) }\end{array}$ & $\begin{array}{l}\text { ECHAM5- } \\
\text { HAMMOZ } \\
\text { (Pozzoli, Bey } \\
\text { et al. 2008) } \\
\text { and GISS } \\
\text { PUCCINI } \\
\text { (Shindell, } \\
\text { Faluvegi et } \\
\text { al. 2006) }\end{array}$ & $\begin{array}{l}\mathrm{CH}_{4}, \\
\mathrm{BC}\end{array}$ & $\begin{array}{l}\text { mortality, } \\
\text { crop loss, } \\
\text { Cost }(\$ \\
\left.\text { tonne }^{-1}\right) \text {, } \\
\text { temperature, } \\
\text { RF }\left(\mathrm{W} \mathrm{m} \mathrm{m}^{-2}\right) \text {, }\end{array}$ \\
\hline $\begin{array}{l}\text { Smith, West } \\
\text { et al. (2011) } \\
\text { West, Smith } \\
\text { et al. (2013) }\end{array}$ & $\begin{array}{l}\text { Global, } 2^{\circ} \mathrm{x} \\
2.5^{\circ} / 1000 \mathrm{~km}^{2}\end{array}$ & $\begin{array}{l}2030 \\
2050, \\
2100\end{array}$ & $\begin{array}{l}2 \text { scenarios } \\
\text { from Global } \\
\text { Change } \\
\text { Assessment } \\
\text { Model } \\
\text { (GCAM) : } \\
\text { RCP4.5 } \\
\text { scenario } \\
\text { (Thomson, } \\
\text { Calvin et al. } \\
\text { 2011), global } \\
\text { carbon price }\end{array}$ & $\begin{array}{l}\text { ERB module in Mini } \\
\text { Climate Assessment } \\
\text { (MiniCAM) model } \\
\text { (Brenkert, Smith et } \\
\text { al. 2003) }\end{array}$ & $\begin{array}{l}\text { MAGICC6 } \\
\text { (Model for } \\
\text { the } \\
\text { Assessment } \\
\text { of } \\
\text { Greenhouse- } \\
\text { gas Induced } \\
\text { Climate } \\
\text { Change) } \\
\text { module in } \\
\text { MiniCAM } \\
\text { model } \\
\text { (Brenkert, } \\
\text { Smith et al. } \\
\text { 2003, } \\
\text { Meinshausen, } \\
\text { Raper et al. } \\
\text { 2011) }\end{array}$ & $\begin{array}{l}\mathrm{PM}_{2.5}, \\
\mathrm{O}_{3}\end{array}$ & $\begin{array}{l}\text { Mortality, } \\
\text { cost } \\
\text { (\$/tonne) }\end{array}$ \\
\hline $\begin{array}{l}\text { van } \\
\text { Aardenne, } \\
\text { Dentener et } \\
\text { al. (2010) }\end{array}$ & $\begin{array}{l}\text { Global, 1x1 } \\
\text { North } \\
\text { America, } \\
\text { Europe, } \\
\text { India, China, } \\
\text { 3x2 } \\
\text { remaining } \\
\text { Northern } \\
\text { Hemisphere, } \\
6 x 4 \\
\text { Southern } \\
\text { Hemisphere }\end{array}$ & 2050 & $\begin{array}{l}6 \text { scenarios: } \\
\text { climate/air } \\
\text { policy alone } \\
\text { or together } \\
\text { with various } \\
\text { country } \\
\text { adoption } \\
\text { from } \\
\text { Prospective } \\
\text { Outlook for } \\
\text { the Long } \\
\text { term Energy } \\
\text { System } \\
\text { (POLES) } \\
\text { model (Russ, } \\
\text { Wiesenthal et } \\
\text { al. 2007) }\end{array}$ & $\begin{array}{l}\text { Emission Database } \\
\text { for Global } \\
\text { Atmospheric } \\
\text { Research (EDGAR) } \\
\text { v4 and GAINS }\end{array}$ & $\begin{array}{l}\text { TM5 (Tracer } \\
\text { Model ver. 5) } \\
\text { (Krol, } \\
\text { Houweling et } \\
\text { al. 2005) }\end{array}$ & $\begin{array}{l}\mathrm{PM}, \\
\mathrm{O}_{3}\end{array}$ & $\begin{array}{l}\text { Crop loss } \\
\text { reduction } \\
(\%), \text { years } \\
\text { life lost/ life } \\
\text { expectancy } \\
\text { (years/perso } \\
\text { n), radiative } \\
\text { forcing } \\
\left(\mathrm{W} / \mathrm{m}^{-2}\right)\end{array}$ \\
\hline
\end{tabular}


Numerous regional and worldwide studies have examined how climate policies and energy scenarios impact air quality, health, and costs as far as 2050 (Table S1). However, the approach and assumptions associated with each study’s energy/climate policy scenarios produce very different outcomes and insights. For instance, some studies

21 produced future energy/climate policy scenarios that are heavily user defined, often on the basis that both pollutants

22 be mitigated. Shindell, Kuylenstierna et al. (2012), used only measures that were "assumed to improve air quality"

23 and mitigate both long-lived GHGs and short-lived criteria pollutants after ranking them by climate impact. The

24 scenario by Jacobson, Delucchi et al. (2014) is defined by 100\% wind, water, sunlight (100\%WWS) renewable

25 supply (and no fossil fuels and biofuels) versus one that is constrained to achieve 80\% GHG emissions reduction

26 such as CA-TIMES GHG-Step. These user-defined measures and energy constraints not only produce different

27 energy projections, but air pollution/health outcomes as well. By permitting only low polluting or zero-emission

28 technologies and policy measures, these scenarios are more heavily defined by the authors/modelers to be somewhat

29 biased to be much cleaner and highly advantageous to human health. The extensive study by van Aardenne,

30 Dentener et al. (2010) explores 6 scenarios with wider levels of air and/or climate policy, as well as the option of

31 biofuel consumption, however, technology adoption is again largely dependent on user specified assumptions on

32 shares of existing technologies. In comparison, this study did not predefine scenario conditions that ensured both

33 criteria pollutants and GHGs would reduce.

34 In contrast, CA-TIMES (1) permits dirtier energy resources (such as biofuels) and measures that don't necessary

35 reduce air pollution, enabling a more conservative pollution outcome, (2) reveals sectors/technology investments

36 and fuel/energy that are most cost-effective rather than user defined choices (3) has more complex new/alternative

37 technology choices, deployment costs, that simpler scenarios ignore. Additional differences exist in the

38 development of the criteria emissions in CA-REMARQUE such as spatial (12 electric utility regions) resource mix

39 growth projections based on SWITCH (Fripp 2012, Johnston, Mileva et al. 2013, Nelson, Mileva et al. 2013) 2050

40 electricity generation projections, optimal biofacility siting locations that comply with potential air quality

41 permitting restrictions (Tittmann, Parker et al. 2010, Parker 2012), and alternative fuel and regenerative braking

42 emission rates based on alternative fuel emission literature. 
Table S3: Population growth rate between 2050 and 2010.

\begin{tabular}{lclc}
\hline County & $\begin{array}{c}\text { 2050:2010 } \\
\text { Population }\end{array}$ & County & $\begin{array}{c}\mathbf{2 0 5 0 : 2 0 1 0} \\
\text { Population }\end{array}$ \\
\hline Alameda & 1.113 & Orange & 1.102 \\
\hline Alpine & 0.985 & Placer & 1.562 \\
\hline Amador & 1.184 & Plumas & 0.983 \\
\hline Butte & 1.515 & Riverside & 1.747 \\
\hline Calaveras & 1.321 & Sacramento & 1.452 \\
\hline Colusa & 1.711 & San Benito & 1.479 \\
\hline Contra Costa & 1.415 & San Bernardino & 1.594 \\
\hline Del Norte & 1.127 & San Diego & 1.279 \\
\hline El Dorado & 1.565 & San Francisco & 1.126 \\
\hline Fresno & 1.619 & San Joaquin & 2.009 \\
\hline Glenn & 1.351 & San Luis Obispo & 1.256 \\
\hline Humboldt & 1.099 & San Mateo & 1.244 \\
\hline Imperial & 1.863 & Santa Barbara & 1.194 \\
\hline Inyo & 1.244 & Santa Clara & 1.205 \\
\hline Kern & 2.209 & Santa Cruz & 1.153 \\
\hline Kings & 1.706 & Shasta & 1.46 \\
\hline Lake & 1.636 & Sierra & 1.125 \\
\hline Lassen & 1.183 & Siskiyou & 1.161 \\
\hline Los Angeles & 1.164 & Solano & 1.435 \\
\hline Madera & 2.138 & Sonoma & 1.237 \\
\hline Marin & 1.048 & Stanislaus & 1.673 \\
\hline Mariposa & 1.264 & Sutter & 2.241 \\
\hline Mendocino & 1.136 & Tehama & 1.551 \\
\hline Merced & 1.941 & Trinity & 1.325 \\
\hline Modoc & 1.119 & Tulare & 1.77 \\
\hline Mono & 1.335 & Tuolumne & 1.118 \\
\hline Monterey & 1.304 & Ventura & 1.207 \\
\hline Napa & 1.354 & Yolo & 1.476 \\
\hline Nevada & 1.425 & Yuba & 1.991 \\
\hline & & & \\
\hline
\end{tabular}




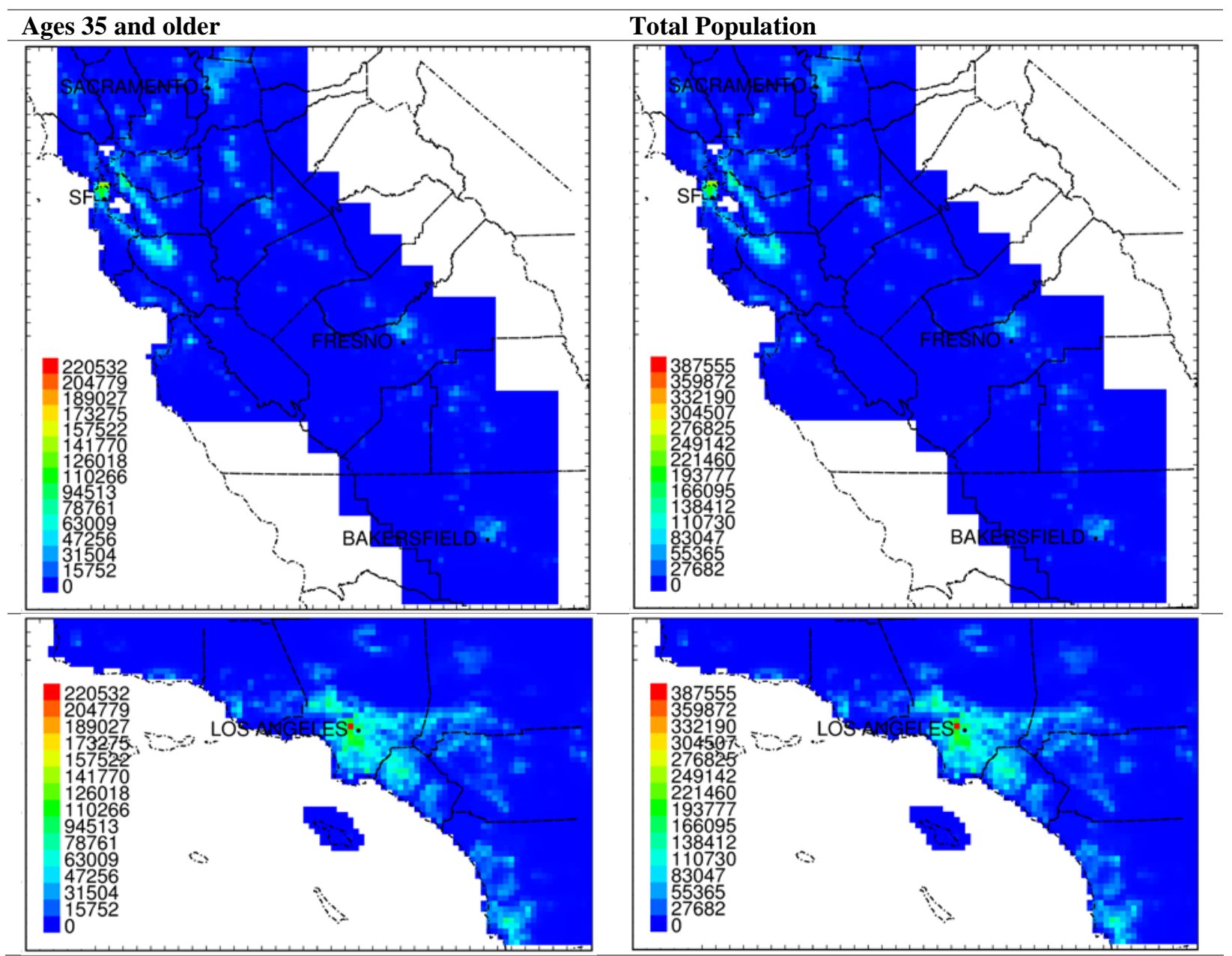

Figure S1: 2050 population projection. The population is projected using 2010 census block group population of Finance. Demographic Research Unit 2014). 
52 Both $4 \mathrm{~km}$ domains combined constitute about $93 \%$ of the state's projected population. The maximum population

53 density occurs in areas surrounding downtown Los Angeles and the San Francisco Financial District. The

54 population ages 35 and older represent roughly $57 \%$ of the total all age group population for either domain.

55

56

Table S4: 2050 population summary.

\begin{tabular}{ccccc}
\hline Region Type & Region & $\begin{array}{c}\text { Area } \\
\left.\mathbf{( k m}^{\mathbf{2}}\right)\end{array}$ & $\begin{array}{c}\text { Population } \\
\text { (persons) }\end{array}$ & $\begin{array}{c}\text { Percentage of the } \\
\text { CA Population (\%) }\end{array}$ \\
\hline Domain Total & CA statewide & 162912.0 & $57,952,084$ & $92.6 \%$ \\
\hline Domain & Northern/ Central CA & 94464.00 & $22,946,980$ & $36.7 \%$ \\
\hline Basin & San Francisco (SF) & 14422.26 & $11,611,289$ & $18.5 \%$ \\
\hline Basin & San Joaquin Valley (SJV) & 46881.20 & $6,426,141$ & $10.3 \%$ \\
\hline Domain & Southern CA & 68448.00 & $35,005,104$ & $55.9 \%$ \\
\hline Basin & South Coast (SC) & 16773.50 & $26,069,030$ & $41.6 \%$ \\
\hline Basin & San Diego (SD) & 7756.350 & $4,825,970$ & $7.7 \%$ \\
\hline
\end{tabular}

Table S5: California 8-hour O3 nonattainment areas and attainment dates as of June 16, 2016. Design values are listed from designation in 2008-2010.

\begin{tabular}{|c|c|c|c|c|c|c|}
\hline Area Name & $\begin{array}{l}\text { Design } \\
\text { Values } \\
\text { (ppm) }\end{array}$ & Classification & $\begin{array}{l}\text { Expected } \\
\text { Attainment } \\
\text { Date }\end{array}$ & $\begin{array}{c}\text { Number } \\
\text { of } \\
\text { Counties }\end{array}$ & $\begin{array}{c}2010 \\
\text { Population }\end{array}$ & $\begin{array}{l}\text { Percent of } \\
\text { Population }\end{array}$ \\
\hline $\begin{array}{l}\text { Los Angeles-South } \\
\text { Coast Air Basin }\end{array}$ & 0.112 & Extreme & 2031 & 4 & $15,719,485$ & $45.4 \%$ \\
\hline San Joaquin Valley & 0.104 & Extreme & 2031 & 8 & $3,842,365$ & $11.1 \%$ \\
\hline $\begin{array}{l}\text { Riverside Co, (Coachella } \\
\text { Valley) }\end{array}$ & 0.095 & Extreme & 2026 & 1 & 425,806 & $1.2 \%$ \\
\hline $\begin{array}{l}\text { Los Angeles-San } \\
\text { Bernardino Counties } \\
\text { (West Mojave Desert) }\end{array}$ & 0.099 & Severe 15 & 2026 & 2 & 868,380 & $2.5 \%$ \\
\hline Sacramento Metro & 0.095 & Severe 15 & 2026 & 6 & $2,241,057$ & $6.5 \%$ \\
\hline Ventura County & 0.086 & Serious & 2020 & 1 & 823,262 & $2.4 \%$ \\
\hline Kern Co (Eastern Kern) & 0.083 & Moderate & 2017 & 1 & 95,176 & $0.3 \%$ \\
\hline San Diego County & 0.082 & Moderate & 2017 & 1 & $3,095,199$ & $8.9 \%$ \\
\hline $\begin{array}{l}\text { Nevada Co. (Western } \\
\text { part) }\end{array}$ & 0.079 & Moderate & 2017 & 1 & 82,107 & $0.2 \%$ \\
\hline Imperial County & 0.078 & Moderate & 2017 & 1 & 174,528 & $0.5 \%$ \\
\hline Mariposa County & 0.077 & Moderate & 2017 & 1 & 18,251 & $0.1 \%$ \\
\hline San Francisco Bay Area & 0.080 & Marginal & 2015 & 9 & $6,973,020$ & $20.1 \%$ \\
\hline Chico (Butte County) & 0.079 & Marginal & 2015 & 1 & 220,000 & $0.6 \%$ \\
\hline $\begin{array}{l}\text { San Luis Obispo } \\
\text { (Eastern San Luis } \\
\text { Obispo) }\end{array}$ & 0.078 & Marginal & 2015 & 1 & 1,649 & $0.0 \%$ \\
\hline Calaveras County & 0.077 & Marginal & 2015 & 1 & 45,578 & $0.1 \%$ \\
\hline Tuscan Buttes & 0.076 & Marginal & 2015 & 1 & 0 & $0.0 \%$ \\
\hline
\end{tabular}




\section{S1 PM2.5 Species Concentration Results}

64

\section{S1.1 PM2.5 Nitrogen containing species}

Table S3 summarizes population-weighted BAU PM $\mathrm{PM}_{2.5}$ concentrations and changes induced by the GHG-Step scenario across different locations in California. The results in Table S3 are broken down by chemical species for an improved understanding of the different sources and atmospheric processes involved in the total particulate matter reductions. Nitrate $\left(\mathrm{NO}_{3}{ }^{-}\right)$accounts for $17 \%$ of the statewide population-weighted $\mathrm{PM}_{2.5}$ mass concentrations in the BAU scenario ( $2{ }^{\text {nd }}$ most dominant chemical species) with contributions as high as $19 \%$ for SD and as low as $15 \%$ for the SJV. Population-weighted nitrate concentrations decrease by $49 \%-50 \%$ in SD and the SJV in the GHG-Step scenario, with more modest reductions in San Francisco (-45 \%) and Los Angeles (-34 \%). Most of this nitrate reduction is associated with lower $\mathrm{NO}_{\mathrm{x}}$ emissions from avoided combustion through the adoption of electric

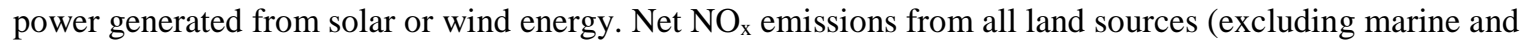
aviation) are lower in the GHG-Step scenario. This trend is also reflected in atmospheric concentrations. Population-weighted gas-phase $\mathrm{NO}$ and $\mathrm{NO}_{\mathrm{x}}\left(\mathrm{NO}+\mathrm{NO}_{2}\right)$ concentrations fall by $71 \%$ and $46 \%$ in the GHG-Step scenario (Table S5).

$\mathrm{PM}_{2.5}$ ammonium $\left(\mathrm{NH}_{4}{ }^{+}\right)$concentrations also decrease in the GHG-Step scenario which contributes strongly to overall $\mathrm{PM}_{2.5}$ reductions, but this trend is not driven by the same source changes that affected nitrate. Ammonium $\left(\mathrm{NH}_{4}{ }^{+}\right)$accounts for $0.57 \mu \mathrm{g} \mathrm{m}{ }^{-3}$ (6 \%) of the population weighted mass in the BAU scenario with concentrations decreasing by $33 \%$ - $50 \%$ in the GHG-Step scenario. These reductions mainly stemmed from the improved management of animal waste in agricultural operations to produce biogas as a renewable energy source which had the added benefit of reducing ammonia emissions.

\section{S1.2 PM2.5 Carbonaceous Species}

Elemental carbon (EC), primary and secondary organic aerosol (POA and SOA) contribute to $43 \%$ of the statewide population-weighted $\mathrm{PM}_{2.5}$ concentration in the BAU scenario making any changes to these species under the GHGStep scenario extremely important for public health. Statewide average concentrations of $\mathrm{PM}_{2.5}$ EC, POA, and SOA are predicted to decrease in the GHG-Step scenario but the effects are mixed, with both increases and decreases depending on location. There is a significant EC increase of $1.0 \mu \mathrm{g} \mathrm{m}^{-3}$ in the GHG-Step scenario in the shipping lanes over the Pacific Ocean near southern California cities of Malibu, Santa Monica and south towards Manhattan Beach due to higher emissions from marine vessels but there is little population exposure associated with this change. All inland locations experience a significant decrease in EC concentrations with the largest reductions around the San Francisco Bay Area where population weighted EC concentration decreases by $38 \%$ from a BAU value of $0.88 \mu \mathrm{g} \mathrm{m}^{-3}$. Statewide, population weighted EC concentrations decrease by $22 \%$ accounting for a $10 \%$ reduction in total population-weighted $\mathrm{PM}_{2.5}$ mass. 
Primary organic aerosol (POA) accounts for approximately 1/3 of $\mathrm{PM}_{2.5}$ mass across all of California including large population centers in the 2050 BAU scenario, but the modest $12 \%$ POA reductions under the GHG-Step scenario yield only a $13.9 \%$ reduction in population-weighted $\mathrm{PM}_{2.5}$ mass concentrations ( $3^{\text {rd }}$ highest). POA reductions occur around emissions sources that are affected by GHG mitigation strategies such as natural gas reduction in the residential and commercial sectors. The population-weighted POA reductions for each basin in order of highest to lowest are SD, SJV, SC, and SF at $19 \%, 16 \%, 14 \%$, and $10 \%$ respectively.

Secondary organic aerosol (SOA) contributes to $1.10 \mu \mathrm{g} \mathrm{m}^{-3}$ (14 \%) of population-weighted $\mathrm{PM}_{2.5}$ mass in the 2050 BAU scenario. Changes to population-weighted $\mathrm{PM}_{2.5}$ SOA concentrations caused by the adoption of the GHGStep scenario were not statistically significant over the majority of California and their individual contributions to $\mathrm{PM}_{2.5}$ mass reduction were not analyzed further in the current study. Updated models of SOA production could change this finding but an exploration of this research topic is outside the scope of the current study.

\section{S1.3 PM 2.5 Sulfate}

107 California adopted low sulfur fuels in the decades after 1980, which greatly reduced $\mathrm{PM}_{2.5}$ sulfate concentrations.

108 Not surprisingly then, statewide population-weighted $\mathrm{PM}_{2.5}$ sulfate $\left(\mathrm{SO}_{4}{ }^{2-}\right)$ concentrations are only $0.39 \mu \mathrm{g} \mathrm{m}^{-3}$ in the 1092050 BAU scenario, which represents $5 \%$ of $\mathrm{PM}_{2.5}$ mass. Some point sources and marine vessels switch to low 110 sulfur biofuels in the GHG-Step scenario, leading to significant decreases in sulfate concentrations in the immediate 111 vicinity around those sources but much smaller changes across other areas. Overall, statewide population-weighted $112 \mathrm{PM}_{2.5}$ sulfate concentrations decrease by 23 \% yielding a 7 \% reduction in population-weighted $\mathrm{PM}_{2.5}$ mass in the

\section{GHG-Step scenario.}

\section{$114 \quad$ S1.4 PM2.5 Metals}

115 In the BAU scenario, copper $(\mathrm{Cu})$, iron $(\mathrm{Fe})$, and manganese $(\mathrm{Mn})$ contribute to a relatively smaller percentage of $116 \mathrm{PM}_{2.5}$ mass. $\mathrm{Cu}$, Fe, and Mn concentrations align strongly with freeways and roads as well as some off-road areas.

117 Population-weighted concentrations of $\mathrm{Cu}, \mathrm{Fe}$, and $\mathrm{Mg}$ have large relative reductions in the GHG-Step scenario (51

$118 \%$ decrease) but still account for modest reductions in total $\mathrm{PM}_{2.5}$ mass (9 \% of the total decrease). Reductions

119 occurred mainly along transportation corridors due to the widespread adoption of regenerative breaking in electric 120 vehicles and hybrid electric vehicles. Regenerative breaking reduces brake wear emissions rich in $\mathrm{Cu}$ and Fe by 121 approximately $59 \%$. Both of these metals are considered to be toxic in airborne particulate matter due to their 122 contribution to oxidative stress. 
Table S5: Annual average population-weighted Business-as-Usual (BAU) concentration and percent change between BAU and GHG-Step scenario for each species and air basin jurisdiction. SJV, SD, SF, SC are the San Joaquin Valley, San Diego, San Francisco, and South Coast air basins, respectively. The statewide or CA value represents roughly $93 \%$ of the population represented by both $4 \mathrm{~km}$ high resolution northern and southern CA modeling domains. All annual average concentration differences between BAU and GHG-Step scenarios were found to have p-values less than 0.1 for all pollutants listed except for those in bold italics mainly SD and SC SOA and SD's 1-hour $\mathrm{O}_{3}$.

\begin{tabular}{|c|c|c|c|c|c|c|c|c|c|c|c|c|}
\hline \multirow{3}{*}{ Pollutant } & \multirow{3}{*}{ Units } & \multirow{3}{*}{ Avg. } & \multicolumn{5}{|c|}{ BAU Concentration } & \multicolumn{5}{|c|}{$\begin{array}{l}\text { GHG-Step Scenario Percentage } \\
\text { Change } \\
\end{array}$} \\
\hline & & & \multicolumn{4}{|c|}{ Air Basin } & \multirow{2}{*}{$\begin{array}{c}\text { State } \\
\text { CA }\end{array}$} & \multicolumn{4}{|c|}{ Air Basin } & \multirow{2}{*}{$\begin{array}{c}\text { State } \\
\text { CA } \\
\end{array}$} \\
\hline & & & SJV & SD & SF & SC & & SJV & SD & SF & SC & \\
\hline \multirow{4}{*}{ Ozone $\left(\mathrm{O}_{3}\right)$} & \multirow{4}{*}{$\mathrm{ppb}$} & $1-\mathrm{hr}$ & & & & & 511 & -4.3 & +0.5 & +6.5 & +5.1 & +2.8 \\
\hline & & max. & 55.9 & 56.8 & 50.1 & 55.2 & 54.1 & $\%$ & $\%$ & $\%$ & $\%$ & $\%$ \\
\hline & & 8-hr & 520 & 510 & 45.0 & 502 & 495 & -3.5 & +2.8 & +9.5 & +5.5 & +3.9 \\
\hline & & $\max$. & $5<.0$ & 01.0 & 40.0 & JU.Z & 49.5 & $\%$ & $\%$ & $\%$ & $\%$ & $\%$ \\
\hline \multirow{2}{*}{ Nitrogen Oxide (NO) } & \multirow{2}{*}{ ppb } & 24-hr & \multirow{2}{*}{0.77} & \multirow{2}{*}{2.77} & \multirow{2}{*}{8.62} & \multirow{2}{*}{2.00} & \multirow{2}{*}{3.15} & -50 & -81 & -82 & -53 & -71 \\
\hline & & avg. & & & & & & $\%$ & $\%$ & $\%$ & $\%$ & $\%$ \\
\hline \multirow{2}{*}{ Nitrogen Dioxide $\left(\mathrm{NO}_{2}\right)$} & \multirow{2}{*}{$\mathrm{ppb}$} & 24-hr & \multirow{2}{*}{6.62} & \multirow{2}{*}{13.8} & 202 & 107 & 121 & -35 & -56 & -46 & -32 & -39 \\
\hline & & avg. & & & 20.2 & 10.7 & 12.1 & $\%$ & $\%$ & $\%$ & $\%$ & $\%$ \\
\hline Nitrogen Oxides (NOy) & $\mathrm{nph}$ & 24-hr & 738 & 165 & 288 & 127 & 153 & -36 & -60 & -57 & -35 & -46 \\
\hline & PPO & avg. & 1.00 & 10.0 & 20.0 & 12.1 & 15.3 & $\%$ & $\%$ & $\%$ & $\%$ & $\%$ \\
\hline Sulfur Dioxide $\left(\mathrm{SO}_{2}\right)$ & $\mathrm{ppm}$ & 24-hr & 0.88 & 0.25 & 0.85 & 0.47 & 0.55 & $-6 \%$ & -30 & -20 & -17 & -16 \\
\hline & Ppili & avg. & 0.00 & 0.25 & 0.03 & 0.47 & 0.03 & & $\%$ & $\%$ & $\%$ & $\%$ \\
\hline PMn mass $\left(\mathrm{PM}_{01}\right)$ & $\mu g$ & 24-hr & 206 & 297 & 359 & 294 & 288 & -35 & -46 & -35 & -31 & -34 \\
\hline 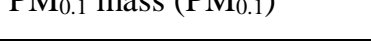 & $\mathrm{m}^{-3}$ & avg. & 2.00 & 2.91 & 0.05 & 2.94 & 2.00 & $\%$ & $\%$ & $\%$ & $\%$ & $\%$ \\
\hline $\operatorname{acs}(\mathrm{PM}-)_{2}$ & & 24-hr & & 837 & 054 & & 763 & -20 & -25 & -19 & -15 & -18 \\
\hline FIVI2.5 IIIdSS (FIVI2.5) & $\mathrm{m}^{-3}$ & avg. & 5.98 & $8.3 /$ & 9.54 & 1.03 & 1.03 & $\%$ & $\%$ & $\%$ & $\%$ & $\%$ \\
\hline $\mathrm{PM}_{2.5}$ elemental carbon & $\mu g$ & 24-hr & 038 & 070 & 088 & 0.59 & 059 & -29 & -34 & -38 & -8.0 & -22 \\
\hline$(\mathrm{EC})$ & $\mathrm{m}^{-3}$ & avg. & 0.30 & 0.10 & 0.00 & 0.59 & 0.39 & $\%$ & $\%$ & $\%$ & $\%$ & $\%$ \\
\hline $\mathrm{PM}_{2.5}$ primary organic & $\mu g$ & 24-hr & 115 & 153 & 201 & 182 & 156 & -16 & -19 & -10 & -14 & -12 \\
\hline aerosol (POA) & $\mathrm{m}^{-3}$ & avg. & 1.15 & 1.03 & 2.01 & 1.02 & 1.50 & $\%$ & $\%$ & $\%$ & $\%$ & $\%$ \\
\hline $\mathrm{PM}_{2.5}$ secondary organic & & 24-hr & 103 & 118 & 085 & 119 & 110 & -8.0 & +0.7 & -2.9 & +0.1 & -2.2 \\
\hline aerosol (SOA) & $\mathrm{m}^{-3}$ & avg. & 1.05 & 1.10 & 0.05 & 1.15 & 1.10 & $\%$ & $\%$ & $\%$ & $\%$ & $\%$ \\
\hline $\mathrm{PM}_{2.5}$ nitrate $\left(\mathrm{NO}_{3}{ }^{-}\right)$ & $\mu g$ & 24-hr & 0.88 & 1.81 & 1.47 & 1.47 & 1.31 & -50 & -49 & -45 & -34 & -39 \\
\hline & $\mathrm{m}^{-3}$ & avg. & & & & & & $\%$ & $\%$ & $\%$ & $\%$ & $\%$ \\
\hline $\mathrm{PM}_{25}$ sulfate $\left(\mathrm{SO}_{4}{ }^{2-}\right)$ & $\mu g$ & 24-hr & 0.36 & 0.55 & 0.51 & 0.47 & 0.39 & -13 & -61 & -23 & -25 & -23 \\
\hline & $\mathrm{m}^{-3}$ & avg. & 0.00 & 0.53 & & & & $\%$ & $\%$ & $\%$ & $\%$ & $\%$ \\
\hline $\mathrm{PM}_{2}{ }_{5}$ ammonium $\left(\mathrm{NH}_{4}^{+}\right)$ & $\mu g$ & 24-hr & 0.44 & 076 & 067 & 063 & 0.57 & -36 & -50 & -36 & -30 & -33 \\
\hline 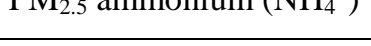 & $\mathrm{m}^{-3}$ & avg. & 0.44 & & 0.07 & 0.05 & 0.07 & $\%$ & $\%$ & $\%$ & $\%$ & $\%$ \\
\hline $\mathrm{PM}_{2.5}$ copper, iron, & $\mu g$ & 24-hr & 0.16 & 035 & 023 & 028 & 025 & -52 & -53 & -52 & -51 & -51 \\
\hline magnesium (Cu, Fe, Mg) & $\mathrm{m}^{-3}$ & avg. & 0.10 & 0.05 & 0.20 & 0.20 & 0.25 & $\%$ & $\%$ & $\%$ & $\%$ & $\%$ \\
\hline $\mathrm{PM}_{25}$ metals & $\mu g$ & 24-hr & 0.14 & 0.33 & 0.29 & 0.26 & 0.25 & -19 & -23 & -17 & -16 & -17 \\
\hline & $\mathrm{m}^{-3}$ & avg. & & & 0.29 & 0.20 & 0.25 & $\%$ & $\%$ & $\%$ & $\%$ & $\%$ \\
\hline $\mathrm{PM}_{2.5}$ other & $\mu \mathrm{g}$ & 24-hr & 0.80 & 0.97 & 0.81 & 0.64 & 0.67 & -2.5 & -20 & -1.9 & -4.7 & -3.1 \\
\hline & $\mathrm{m}^{-3}$ & avg. & & & & & & $\%$ & $\%$ & $\%$ & $\%$ & $\%$ \\
\hline $\mathrm{PM}_{2.5}$ unknown & $\mu g$ & 24-hr & 0.47 & 068 & 157 & 061 & 075 & 0.5 & +2.6 & +2.3 & +1.4 & +2.3 \\
\hline 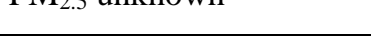 & $\mathrm{m}^{-3}$ & avg. & $0.7 \%$ & & 1.08 & 0.01 & 0.15 & $\%$ & $\%$ & $\%$ & $\%$ & $\%$ \\
\hline PM10 mass $\left(\mathrm{PM}_{10}\right)$ & $\mu g$ & 24-hr & 7.85 & 10.9 & 12.4 & 9.04 & 9.60 & -19 & -21 & -16 & -14 & -16 \\
\hline & & avg. & & & & & & $\%$ & $\%$ & $\%$ & $\%$ & $\%$ \\
\hline
\end{tabular}




\section{S2 PM Size Distribution Results}

Figure S2 summarizes predicted changes to the airborne particle size distribution in the GHG-Step scenario relative to the BAU scenario. Size distribution shifts are caused by changes to emissions sources (which each emit different particle size distributions) and changes to the rate of secondary PM formation (which condense on particles and change the size distribution).

\section{S2.1 Ultrafine particles $(\mathrm{Dp}<0.1 \mu \mathrm{m})$}

$\mathrm{PM}_{0.1}$ mass (mass of particles with diameter $\mathrm{D}_{\mathrm{p}}<0.1 \mu \mathrm{g} \mathrm{m}{ }^{-3}$ ) is substantially reduced in the GHG-Step scenario; $\mathrm{PM}_{0.1}$ decreases are greater than any other size fraction. $\mathrm{BAU} \mathrm{PM}_{0.1}$ concentrations are highest around large combustion sources associated with urban centers and many of these combustion sources are controlled through GHG mitigation measures. Peak $\mathrm{PM}_{0.1}$ concentrations over California in the BAU scenario are predicted to be $5.8 \mu \mathrm{g}$ $\mathrm{m}^{-3}-7.2 \mu \mathrm{g} \mathrm{m}^{-3}$ with GHG-Step reductions of about $2.76 \mu \mathrm{g} \mathrm{m}^{-3}$ in SF, $3.2 \mu \mathrm{g} \mathrm{m}^{-3}$ in SF and in San Bernardino. $\mathrm{PM}_{0.1}$ decreases from a statewide population-weighted average of $2.9 \mu \mathrm{g} \mathrm{m}^{-3}$ in the BAU scenario to $1.9 \mu \mathrm{g} \mathrm{m}^{-3}(-34$ \%) in the GHG-Step scenario. Regionally, population-weighted $\mathrm{PM}_{0.1}$ declines from 31 \%-46 \%, with minimal decline in SC and the highest decline in SD. The $\mathrm{PM}_{0.1}$ mass fraction of $\mathrm{PM}_{10}$ drops from $30 \%$ to $23 \%$ statewide.

\section{S2.2 Accumulation mode $(0.1<\mathrm{Dp}<2.5 \mu \mathrm{m})$}

As expected, the accumulation mode has the highest BAU PM mass with a statewide population-weighted average of $4.8 \mu \mathrm{g} \mathrm{m}^{-3}$ and regional concentrations ranging from 3.9-5.9 $\mathrm{\mu g} \mathrm{m}^{-3}$. Most regions have accumulation mode population-weighted concentrations that are roughly double the ultrafine and coarse mode concentrations. GHG mitigation strategies have less effect on the accumulation mode than on the ultrafine mode. Population-weighted concentrations of accumulation model mass decrease by $0.35 \mu \mathrm{g} \mathrm{m}^{-3}(-7.4 \%)$ but their contribution to $\mathrm{PM}_{2.5}$ mass increases from $50 \%$ in the BAU scenario to $54 \%$ in the GHG-Step scenario. This statewide trend is reflected in all regions of California.

\section{S2.3 Coarse mode $(\mathrm{Dp}>2.5 \mu \mathrm{m})$}

Particles in the coarse mode ( $\mathrm{Dp}>2.5 \mu \mathrm{m}$ ) are predicted to contribute to $20.5 \%$ of the population-weighted $\mathrm{PM}_{10}$ mass across California in the BAU scenario. The GHG-Step scenario is predicted to decrease concentrations of coarse mode particles by $0.17 \mu \mathrm{g} \mathrm{m}^{-3}$ (-8.7\%), which is the smallest amount for any of the size ranges considered.

\section{S2.4 Particulate size distribution shift}

As the chemical composition of PM changes from fuel and energy consumption changes, the size distribution will also change. Smaller ultrafine particles of $\mathrm{PM}_{0-0.1}$ drop steeper than fine $\mathrm{PM}_{2.5-10}$ and coarse $\geq \mathrm{PM}_{10}$. Since primary emissions from combustion have a size distribution profile that skews towards ultrafine PM, it explains why the ultrafine mode would reduce substantially. Reductions in the accumulation mode $\mathrm{PM}_{2.5-1}$ largely attributes to the 
sulfate and nitrate particles that are largely caused gas-to-particle partitioning of $\mathrm{NO}_{\mathrm{x}}$ and $\mathrm{SO}_{\mathrm{x}}$ into the aqueous phase. The coarse $\geq \mathrm{PM}_{10}$ decline likely attributes to the reduction of brake wear metals such as $\mathrm{Cu}, \mathrm{Mg}$, and Fe.

Figure S1: Particulate size mode concentration for BAU scenario and GHG-Step-BAU scenario difference.

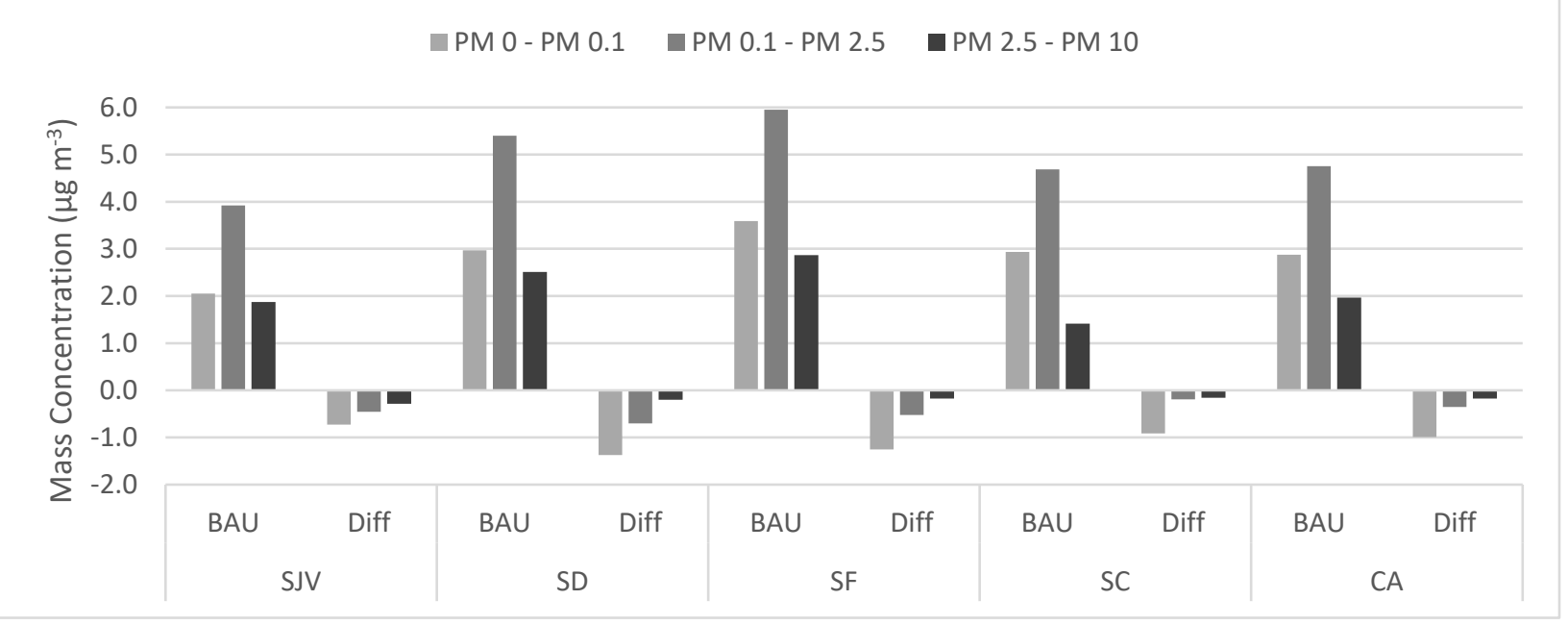

\section{References}

Brenkert, A., A. Smith, S. Kim and H. Pitcher (2003). Model Documentation for the MiniCAM. U. S. D. o. Energy. Pacific Northwest National Laboratory, Pacific Northwest National Laboratory, Richland, Washington 99352.

California Department of Finance. Demographic Research Unit (2014). P-2: State and County Population Projections - Race/Ethnicity and 5-Year Age Groups. 2010 through 2060. W. Schwarm. Sacramento, CA. Fripp, M. (2012). "Switch: a planning tool for power systems with large shares of intermittent renewable energy." Environ Sci Technol 46(11): 6371-6378.

GAINS Development Team. International Institute for Applied Systems Analysis (IIASA) (2009).

GAINS Online: Tutorial for advanced users. Version 1.0. Schlossplatz 1, A-2361 Laxenburg, Austria, International Institute for Applied Systems Analysis (IIASA).

Garcia-Menendez, F., R. K. Saari, E. Monier and N. E. Selin (2015). "U.S. Air Quality and Health Benefits from Avoided Climate Change under Greenhouse Gas Mitigation." Environ Sci Technol 49(13): 7580-7588.

Jacobson, M. Z., M. A. Delucchi, A. R. Ingraffea, R. W. Howarth, G. Bazouin, B. Bridgeland, K. Burkart, M. Chang, N. Chowdhury, R. Cook, G. Escher, M. Galka, L. Han, C. Heavey, A. Hernandez, D. F. Jacobson, D. S. Jacobson, B. Miranda, G. Novotny, M. Pellat, P. Quach, A. Romano, D. Stewart, L. Vogel, S. Wang, H. Wang, L. Willman and T. Yeskoo (2014). "A roadmap for repowering California for all purposes with wind, water, and sunlight." Energy 73: 875-889.

Jacobson, M. Z., Y. J. Kaufman and Y. Rudich (2007). "Examining feedbacks of aerosols to urban climate with a model that treats 3-D clouds with aerosol inclusions." Journal of Geophysical Research 112(D24). Johnston, J., A. Mileva, J. H. Nelson and D. M. Kammen (2013). SWITCH-WECC. Data, Assumptions, and Model Formulation. Berkeley, California, Renewable and Appropriate Energy Laboratory. Kleeman, M. J. and G. R. Cass (2001). "A 3D Eulerian Source-Oriented Model for an Externally Mixed Aerosol." Environmental Science \& Technology 35(24): 4834-4848.

Kleeman, M. J., G. R. Cass and A. Eldering (1997). "Modeling the airborne particle complex as a sourceoriented external mixture." Journal of Geophysical Research: Atmospheres 102(D17): 21355-21372. 
Krol, M., S. Houweling, B. Bregman, M. van den Broek, A. Segers, P. van Velthoven, W. Peters, F. Dentener and P. Bergamaschi (2005). "The two-way nested global chemistry-transport zoom model TM5: algorithm and applications." Atmos. Chem. Phys. 5(2): 417-432. Lamarque, J. F., L. K. Emmons, P. G. Hess, D. E. Kinnison, S. Tilmes, F. Vitt, C. L. Heald, E. A. Holland, P. H. Lauritzen, J. Neu, J. J. Orlando, P. J. Rasch and G. K. Tyndall (2012). "CAM-chem: description and evaluation of interactive atmospheric chemistry in the Community Earth System Model." Geoscientific Model Development 5(2): 369-411.

Meinshausen, M., S. C. B. Raper and T. M. L. Wigley (2011). "Emulating coupled atmosphere-ocean and carbon cycle models with a simpler model, MAGICC6 - Part 1: Model description and calibration." Atmospheric Chemistry and Physics 11(4): 1417-1456.

Nelson, D. J., A. Mileva, J. Johnston and P. D. Kammen (2013). Scenarios for Deep Carbon Emission Reductions from Electricity by 2050 in Western North America Using the SWITCH Power Electric Power Sector Planning Model. California's Carbon Challenge Phase II. California Energy Commission. 310 Barrows Hall Berkeley, CA 94720-3050, University of California, Berkeley, Renewable and Appropriate Energy Laboratory Energy and Resources Group. II: 142.

Paltsev, S., J. M. Reilly, H. D. Jacoby, R. S. Eckaus, J. McFarland, M. Sarofim, M. Asadoorian and M. Babiker (2005). The MIT Emissions Prediction and Policy Analysis (EPPA) Model: Version 4. MIT Joint Program on the Science and Policy of Global Change. Joint Program on the Science and Policy of Global Change, 77 Massachusetts Avenue, MIT E40-428, Cambridge MA 02139-4307 (USA), Massachusetts Institute of Technology (MIT).

Parker, N. (2012). "Spatially Explicit Projection of Biofuel Supply for Meeting Renewable Fuel Standard." Transportation Research Record: Journal of the Transportation Research Board 2287: 72-79. Pozzoli, L., I. Bey, S. Rast, M. G. Schultz, P. Stier and J. Feichter (2008). "Trace gas and aerosol interactions in the fully coupled model of aerosol-chemistry-climate ECHAM5-HAMMOZ: 1. Model description and insights from the spring 2001 TRACE-P experiment." Journal of Geophysical Research 113(D7).

Russ, P., T. Wiesenthal, D. van Regemorter and J. Ciscar (2007). Global Climate Policy Scenarios for 2030 and beyond. Analysis of Greenhouse Gas Emission Reduction Pathway Scenarios with the POLES and GEM-E3 models., European Commission. Joint Research Centre. Institute for Prospective Technological Studies.

Shindell, D., J. C. I. Kuylenstierna, E. Vignati, R. van Dingenen, M. Amann, Z. Klimont, S. C. Anenberg, N. Muller, G. Janssens-Maenhout, F. Raes, J. Schwartz, G. Faluvegi, L. Pozzoli, K. Kupiainen, L. Höglund-Isaksson, L. Emberson, D. Streets, V. Ramanathan, K. Hicks, N. T. K. Oanh, G. Milly, M. Williams, V. Demkine and D. Fowler (2012). "Simultaneously Mitigating Near-Term Climate Change and Improving Human Health and Food Security." Science 335(6065): 183.

Shindell, D. T., G. Faluvegi, N. Unger, E. Aguilar, G. A. Schmidt, D. M. Koch, S. E. Bauer and R. L. Miller (2006). "Simulations of preindustrial, present-day, and 2100 conditions in the NASA GISS composition and climate model G-PUCCINI." Atmos. Chem. Phys. 6(12): 4427-4459.

Smith, S. J., J. J. West and P. Kyle (2011). "Economically consistent long-term scenarios for air pollutant emissions." Climatic Change 108(3): 619.

Thomson, A. M., K. V. Calvin, S. J. Smith, G. P. Kyle, A. Volke, P. Patel, S. Delgado-Arias, B. BondLamberty, M. A. Wise, L. E. Clarke and J. A. Edmonds (2011). "RCP4.5: a pathway for stabilization of radiative forcing by 2100." Climatic Change 109(1-2): 77-94.

Tittmann, P. W., N. C. Parker, Q. J. Hart and B. M. Jenkins (2010). "A spatially explicit techno-economic model of bioenergy and biofuels production in California." Journal of Transport Geography 18(6): 715728.

van Aardenne, J., F. Dentener, R. Van Dingenen, G. Maenhout, E. Marmer, E. Vignati, P. Russ, L. Szabo and F. Raes (2010). Climate and air quality impacts of combined climate change and air pollution policy scenarios. JRC Scientific and Technical Reports. Luxembourg: Publications Office of the European Union, European Commission. Joint Research Centre. Institute for Environment and Sustainability. 
247 West, J. J., S. J. Smith, R. A. Silva, V. Naik, Y. Zhang, Z. Adelman, M. M. Fry, S. Anenberg, L. W.

248 Horowitz and J. F. Lamarque (2013). "Co-benefits of Global Greenhouse Gas Mitigation for Future Air

249 Quality and Human Health." Nat Clim Chang 3(10): 885-889.

250 Yang, C., S. Yeh, K. Ramea, S. Zakerinia, D. McCollum, D. Bunch and J. Ogden (2014). Modeling

251 Optimal Transition Pathways to a Low Carbon Economy in California: California TIMES (CA-TIMES)

252 Model. Davis, CA., Institute of Transportation Studies, University of California, Davis.

253 Yang, C., S. Yeh, S. Zakerinia, K. Ramea and D. McCollum (2015). "Achieving California's 80\%

254 greenhouse gas reduction target in 2050: Technology, policy and scenario analysis using CA-TIMES

255 energy economic systems model." Energy Policy 77: 118-130.

256 Ying, Q., M. P. Fraser, R. J. Griffin, J. Chen and M. J. Kleeman (2007). "Verification of a source-oriented 257 externally mixed air quality model during a severe photochemical smog episode." Atmospheric

258 Environment 41(7): 1521-1538. 